\title{
Measures of Improving Unpopular Professions Undergraduates' Employment Ability-Taking Mineral Processing Engineering Major as an Example
}

\author{
Fu Yang ${ }^{\mathrm{a}}$ and Gongming Qian ${ }^{\mathrm{b}}$ * \\ (Hubei Key Laboratory for Efficient Utilization and Agglomeration of Metallurgic Mineral Resources, \\ Wuhan University of Science and Technology, Wuhan, 430081, China) \\ a542734663@qq.com, bmoneyfamous@163.com
}

Keywords: Unpopular profession; Employment measures; Undergraduate; Employment situation

\begin{abstract}
With the rapid development of society and economy, and continuously expanding enrollment, higher education in China has entered the popularized stage. Nowadays, the situation of undergraduates' employment is becoming increasingly grim in our country. Undergraduates' employment problem has been a widely concerned issue. The paper analyzed the actuality of mineral processing engineering major undergraduates' employment, researched the existing problems and proposed some countermeasures. The paper can provide scientific references for college and university solving the problem of unpopular professions undergraduates' employment.
\end{abstract}

\section{The Actuality of Undergraduates' Employment}

Since 1999, the number of college graduates in China increase rates has remained at about $20 \%$ every year ${ }^{[1]}$. Colleges and universities provide a large number of graduates for the talent market every year. The large increase in the number of graduates each year caused a glut on the talent market, which has increased the difficulty of the graduates' employment. As the iron and steel industry continues to face market oversupply. Iron and steel enterprises suffers heavy losses. Many iron and steel enterprises adopt measures to limit production, stop production, and even lay off employees. As a result, a lot of iron and steel enterprises are forced to shrink even freeze recruitment plan ${ }^{[2-4]}$. For the mineral processing engineering major, students' major is related to the steel industry, such as mineral separation, sinter, pellet. The number of recruitment of iron and steel enterprises is less, so graduates face great employment pressure. Even if some graduates find a job, due to industry downturn, they also face the confusion of low wages. It universally exists among graduates that the employment pressure is great. They also have no confidence in the future of iron and steel industry's development. Even dislike of studying is riding among students. Some students want to change major, to improve their employability and competitiveness. Many students can't correctly understand their own major, complain and negative pessimistically, do not improve their own comprehensive quality. These negative and aimless ideas of choosing-job make their employment competitiveness discount greatly, thus they pass by many employment opportunities ${ }^{[5-7]}$.

On the other hand, the developments of iron and steel industry are uneven, and structural contradictions are still outstanding. For smaller iron and steel companies, the demand of talents is relatively small. The talent demand of large iron and steel companies in developed areas is basically at saturation point. And the competition in these companies was fierce. But talents of many iron and steel companies in underdeveloped areas are seriously lacking. But due to factors such as treatment, graduates' job-hunting intention is low. In addition, the mineral processing engineering major is specialized, graduates' job prospect is pretty limited, and recruiting seasons of many iron and steel companies are later, etc., In a word, there are more disadvantages. 


\section{The Employment Measures}

Strengthening Professional Education. First, to strengthen the reform of curriculum and teaching management, and to expand the depth and breadth of basic knowledge build a complete theoretical system for undergraduates of the mineral processing engineering major. Offering new courses, such as environmental protection, comprehensive utilization of secondary mineral resources, etc., thereby broadens the graduates' employment opportunities. Second, undergraduates' cognition of employment and employment adaptability are improved by strengthening the proportion of practice teaching and highlighting the role of the practice. Through practice, undergraduates can further understand internal information of related industries, can make them better adapt to the new job environment ${ }^{[8-9]}$. Finally, it is essential to let the students fully understand majors are no good or bad. Now employers pay more attention to the overall qualities of undergraduates, such as practical performing ability, expression ability and interpersonal skills. Professional knowledge is of vital importance, however, even if they find a good job, they also won't have a good personal development without respect-work spirit and ability to communicate with people. So, at the same time of learning professional knowledge well, undergraduates of the mineral processing engineering major must improve their comprehensive quality to better adapt to more work ${ }^{[10-11]}$.

Strengthen Cooperation Between School and Enterprises. The measures include establishing relations with high-quality enterprises, school-enterprise cooperation, customized training, and establishing practice base. Off-campus practice bases, for example, provide a good platform to positive interaction with enterprises. The university provides technical support for the enterprise, and solves the "bottleneck" problems for the development of enterprises. As well as this lays a good foundation for publicity and promotion graduates employment. The university invites skillful craftsmen of the enterprises and technical experts to take lessons for the undergraduates. Teachers integrate new technologies and new processes into theory teaching and practice teaching to improve education quality of teaching. Using of the enterprises platforms provide higher level of training platform for students. In this way, multi -win goals of enterprise getting talents, undergraduates having jobs, university getting development ${ }^{[12]}$.

The Necessary Psychological Counseling for Undergraduates. To strengthen the ideological and political education is the important section and basic guaranty for the work of graduate's obtaining employments. Taking a variety of means such as lecture, make undergraduates understand the professional, and set up the correct professional idea. At the same time, university attaches importance to ideological and political education, improves the employment psychological guidance and the methods of training of starting up business. Strengthen training of the graduates' employment skills training. And the university has started to construct specialized teaching staff, and the courses to guide the employment of university students have been formally listed in teaching plan. In order to train compound person masters many skills, emphasized the specialized curriculum and the society request to tie. The employers are invited to communicate with students, and to solve the problems of university students' employment psychological pressure together with the school. Let students know employment condition and development of the information of this professional Previous graduates to enhance their confidence in professional. Make students acquire self-cognition ability, make suitable academic and career plans, and implement them scientifically in practice. Transform students' thoughts on ultimately relying on professional. It is proved by practices that students' major in university cannot be set for their life. And students can really learn in university including learning ability, thinking ability, interpersonal ability and the ability of themselves-development ${ }^{[13]}$.

Implementation of Employment Work. The university sets up the principle that teachers regard students as foundation. The university must care about what students care about. Employment word is a very important work and an important index of the core competitiveness to the university. Graduate employment work is vital for long-term development of the university. In order to ensure the smooth 
implementation of employment work, it has established leading group headed by the dean, secretary as a foreman and acting foreman. The main force of employment work includes head teachers of terminal classes, counselors and college party leaders. School administrators, teachers and students have been asked to participate in employment work. As a result, work pattern of the university leading, departments cooperating and all the staff participating in has already been formed.

\section{Summary}

The university students in the new periods are faced with huge pressure of employment. As well as there are a large number of employment opportunities. Guide students to full employment, It needs the joint efforts of universities, enterprises, government, and so as to create employment opportunities for graduates, to improve students' employment abilities, and to better serve the country contribute to the country. At the same time, make university students establish the confidence of employment and entrepreneurship and correctly understand their own ability and level. Encourage students to respond resiliently to employment pressure and challenges from the realities. To the problem of unpopular professions undergraduates' employment, it requires guidance of policy, the support of social power, at the same time also needs schools to explore new ideas and new methods. Only joint efforts and join forces to take different measures, to effectively solve the problem of unpopular professions undergraduates' employment. Overall, our university has done a lot in this area and obtained some effect. In the continue practice, the university must make it the goal to train students innovative quality and the core to cultivate students the core competitive power so as to cultivate more talents for our society.

\section{Acknowledgements}

Fund Project: Teaching-research Item of the Wuhan University of Science and Technology (NO: 2015X058)

\section{Reference}

[1] C.P. Chang and K. Q. Ding: Education Teaching Forum, (2017) No.8, p.35. (In Chinese)

[2] Information on http://finance.people.com.cnl

[3] Information on http://money.163.coml

[4] Information on http://finance.sina.com.cn

[5] S. Yang and L.P. Xie: Science and Technology Visio, (2016) No.26, p.70. (In Chinese)

[6] H.N. Li and J. Fu: Modern Business Trade Industry, (2016) No.26, p.92. (In Chinese)

[7] Y. Li, Y.F. Wang and C.Y. Li: Human Resource Management (2016) No.5, p.273. (In Chinese)

[8] Z.L. Gu: Education Teaching Forum, (2011) No.26, p.23. (In Chinese)

[9] Q. Deng: Education and Vocation, (2015) No.33, p.82. (In Chinese)

[10]Y. Quan: Science and Technology Information, (2007) No.28, p.122. (In Chinese).

[11]G.X. Li: Talent Resources Development, (2016) No.18, p.67. (In Chinese).

[12]F. Yang and G.M. Qian: China Metallurgical Education, (2016) No.6, p.64. (In Chinese).

[13] S.X. Hu: Journal of Hubei Radio and Television University, Vol. 35 (2015) No.3, p.31. (In Chinese). 